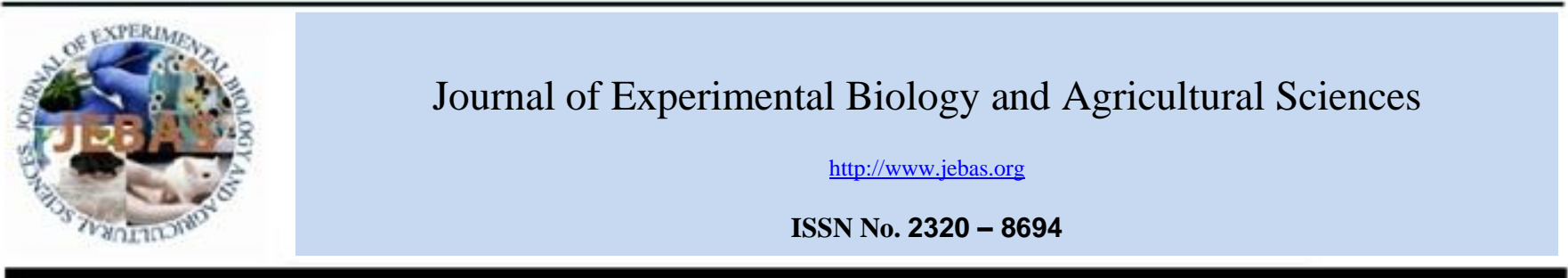

\title{
SOIL TEST BASED FERTILIZATION RECOMMENDATIONS OF ECONOMICS AND NUTRIENT COMPOSITION OF MUSTARD ON INCEPTISOL
}

\author{
Kumari Kiran, Y.V. Singh*, Sanjay Swami, Pavan Singh, Satya Prakash Vishwakarma, \\ Shukritte, Shalini Sharma
}

Department of Soil Science and Agricultural Chemistry, Institute of Agricultural Sciences, Banaras Hindu University, Varanasi 221005 , Uttar Pradesh

Received - December 29, 2020; Revision - September 04, 2021; Accepted - September 06, 2021

Available Online - October 20, 2021

DOI: http://dx.doi.org/10.18006/2021.9(Spl-3-NRMCSSA_2021).S358.S363

\section{KEYWORDS \\ Inorganic fertilizers \\ FYM \\ Mustard \\ STCR \\ Economic \\ Nutrient composition}

\begin{abstract}
During the winter (Rabi) season of 2019-20, the experiment was conducted in a farmer's field in the village of Loharapur, Varanasi, to investigate the impact of nutrient management technologies in alluvial soil with farmyard manure and various levels of inorganic fertilizers under mustard (Brassica juncea L.). Based on the STCR target yield idea, the use of plant nutrients has achieved mustard (18.0 q $\left.\mathrm{ha}^{-1}\right)$ and $\left(22.0 \mathrm{q} \mathrm{ha}^{-1}\right)$ outputs (soil test crop response technology). The test results indicated that the target yields were reached within $+5 \%$ of site modifications, confirming the validity of the formulae used to prescribe integrated mortar fertilizer dosages. For RDF, the highest production increases of $22 \mathrm{q}$ $\mathrm{ha}^{-1}(37,60 \%)$, followed by $18 \mathrm{q} \mathrm{ha}^{-1}$ were recorded (12.05 percent). The maximum cost-effectiveness and profit rate of $22.00 \mathrm{q} \mathrm{ha}^{-1}$ was the result. Organic carbon content is positive and significantly connected to the activity of the enzyme. As a consequence, the combination of NPK and FYM has been more successful in improving the productivity of rice aimed at $18 \mathrm{q} \mathrm{ha}^{-1}, 22 \mathrm{q} \mathrm{ha}^{-1}$, and soil nutritional status than a single application of FYM or chemical fertilizer. Significant net benefits of mustard at the site (Rs 55,190.00 and Rs 38,583.00) in the treatment of plant nutrient levels in the soil test; (STCR treatment). Though fertilization enhanced mustard production above control, it was reported that using NPK and FYM together was more successful than using them alone in increasing mustard productivity.
\end{abstract}

* Corresponding author

E-mail: yvsingh59@rediffmail.com(Y.V.Singh)

Peer review under responsibility of Journal of Experimental Biology and Agricultural Sciences.

Production and Hosting by Horizon Publisher India [HPI] (http://www.horizonpublisherindia.in/).

All rights reserved.
All the articles published by Journal of Experimental Biology and Agricultural Sciences are licensed under a Creative Commons Attribution-NonCommercial 4.0 International License Based on a work at www.jebas.org.

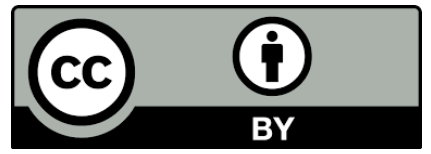




\section{Introduction}

One of the most essential elements of our daily diet is edible oil. Oilseeds are important in agricultural industries and international trade, in addition to providing essential raw materials for agro-based enterprises. The Brassica crop, namely oilseed rape, produces a significant volume of edible oil, as well as a method of generating high quantities of high-quality oil for human consumption from a global viewpoint. India dominates the oilseed landscape, accounting for 12-15 percent of the world's under oilseeds region. The oilseed sector is critical to agriculture and the economy.

By 2050, India would need to produce 17.84 million tonnes of vegetable oils to meet the nutritional fat demands of its estimated 1685 million people at the current level of technology and resource management in Indian agriculture, this goal is exceedingly difficult to achieve (Hegde, 2012). As a result, boosting the production of oilseeds is critical for self-sufficiency. To do this, the number of nutrients lost from the soil must be replaced by the careful use of fertilizers and manures.

After Rajasthan, Uttar Pradesh is the second-largest mustard producer. According to government estimates for 2016-17, mustard is cultivated on 7, 85,000 hectares in Uttar Pradesh, with an output of around 8,48,000 tonnes and productivity of $1080 \mathrm{~kg}$ $\mathrm{ha}^{-1}$ area. Uttar Pradesh has a pleasant temperature, large regions of fertile soils, plenty of sunshine, and ample water supplies. Unbalanced fertilization of $\mathrm{N}, \mathrm{P}$, and $\mathrm{K}$ nutrients is one of the causes of decreased production. Farmers' capacity to apply appropriate amounts of fertilizers to crops is limited by the high cost of fertilizers and their non-availability during lean periods. If fertilizers are applied under an integrated plant nutrition system (IPNS) based on a soil test, fertilizer consumption can be reduced. At a rate of 10 million tons per year, the net balance of plant nutrients in Indian agriculture is negative (Ramakrishna Parama \& Munawery, 2012). One of the reasons for lower output is farmers unbalanced fertilizer application without the understanding of soil fertility or crop nutrient requirements. This has negative consequences on soil and crop in terms of nutrient toxicity and inadequacy (Rao \& Srivastava 2000; Mandal et al., 2007).

Only suitable organic manure and inorganic fertilizer plan based on soil fertility evaluation can remedy it. Soil test-based fertilizer prescription reduces overuse and underuse of fertilizer inputs, improving fertilizer efficiency and crop production. Soil testing has become one of the most important instruments for boosting agricultural yields through proper fertilizer prescription and soil fertility maintenance. Graduated dosages of fertilizers were applied to create a macrocosm of soil fertility variations within a microcosm of an experimental field, a novel field experimental strategy (Inductive methodology) on soil test crop response correlation was developed. The enzymes urease and phosphatase are engaged in the $\mathrm{N}$ and $\mathrm{P}$ cycles, respectively (Badiane et al., 2001). This establishes a solid foundation for balanced fertilization, not just between fertilizer nutrients but also between fertilizer nutrients and nutrients accessible in the soil. In light of the above, farmer field research was conducted for mustard in alluvial soil (Inceptisol) in the eastern plain zone of Uttar Pradesh to validate the fertilizer prescription equation developed using the STCR- INM model.

\section{Materials and Methods}

\subsection{Study area}

During the winter (Rabi) season of 2019-20, the research was conducted on a farmer's field in the village of Loharapur, Varanasi. The availability of $\mathrm{N}, \mathrm{P}$, and $\mathrm{K}$, as well as organic carbon, $\mathrm{pH}$, and enzyme activity, in the soils of the chosen area, were initially determined. Treatments were administered, cultivation procedures were regularly followed, and seed output was assessed at harvest. Using data on seed yield and fertilizer doses, the benefit-cost ratio (B: C) and increase in yield were computed. The study used a Randomized Complete Block Design (RCBD), with seven treatments duplicated three times. $\mathrm{T}_{1}$ : no fertilizer, $\mathrm{T}_{2}$ : farmer's practice: NPK at 80:60:20 $\mathrm{kg} \mathrm{ha}^{-1}, \mathrm{~T}_{3}$ : General recommendation dose@ 100:80:40 NPK kg ha ${ }^{-1}, \mathrm{~T}_{4}$ : Target yield $18 \mathrm{q} \mathrm{ha}^{-1}$, NPK application based on soil test crop response (NPK @ 116: 43.32: $\left.45.78 \mathrm{~kg} \mathrm{ha}^{-1}\right), \mathrm{T}_{5}$ : Target yield $22 \mathrm{q} \mathrm{ha}^{-1}$, NPK application based on soil test crop response (NPK @ 164.80:61.72:63:44 kg ha-1), $\mathrm{T}_{6}$ : Target yield $18 \mathrm{q} \mathrm{ha}^{-1}$, NPK application based on soil test crop

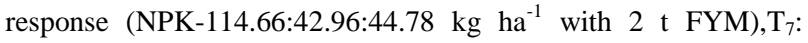
Target yield $22 \mathrm{q} \mathrm{ha}^{-1}$, NPK application based on soil test crop response (NPK-161.66:60.82:60.94 $\mathrm{kg} \mathrm{ha}^{-1}$ with $2 \mathrm{t} \mathrm{FYM).}$

Based on the soil test value, the equation for calculating NPK recommended dose for goal yield was established for alluvial soils in the Varanasi region (Regar \& Singh 2014). The fertilizer dosages for various treatments were computed based on this number, and fertilizer recommendations were made. Utilizing the fertilizer adjustment formulae, a soil test-based recommendation for yield target.

\section{Without FYM}

$$
\begin{aligned}
& \mathrm{FN}=12.2 \mathrm{~T}-0.56 \mathrm{SN} \\
& \mathrm{FP}=4.60 \mathrm{~T}-3.29 \mathrm{SP} \\
& \mathrm{FK}=4.69 \mathrm{~T}-0.24 \mathrm{SK}
\end{aligned}
$$

\section{With FYM}

$$
\begin{aligned}
& \mathrm{FN}=12.2 \mathrm{~T}-0.56 \mathrm{SN}-0.09 \mathrm{ON} \\
& \mathrm{FP}=4.60 \mathrm{~T}-3.29 \mathrm{SP}-0.06 \mathrm{OP} \\
& \mathrm{FK}=4.69 \mathrm{~T}-0.24 \mathrm{SK}-0.05 \mathrm{OK}
\end{aligned}
$$


where, $\mathrm{FN}, \mathrm{FP}_{2} \mathrm{O}_{5}, \mathrm{FK}_{2} \mathrm{O}$ are fertilizers $\mathrm{N}, \mathrm{P}_{2} \mathrm{O}_{5}$ and $\mathrm{K}_{2} \mathrm{O}$ in kg ha ${ }^{-1}$, respectively; $\mathrm{T}=$ Seed yield target in $\mathrm{qha}^{-1} ; \mathrm{SN}, \mathrm{SP}$, and $\mathrm{SK}$ are available $\mathrm{N}, \mathrm{P}$, and $\mathrm{K}$ in $\mathrm{kg} \mathrm{ha}^{-1}$, respectively; $\mathrm{ON}$, OP and $\mathrm{OK}$ are $\mathrm{N}, \mathrm{P}$ and $\mathrm{K}$ supplied through FYM in $\mathrm{kgha}^{-1}$. The number of fertilizer nutrients necessary to achieve $18 \mathrm{q} \mathrm{ha}^{-1}$ and $22 \mathrm{q} \mathrm{ha}^{-1}$ seed yields of mustard were calculated using the aforementioned fertilizer adjustment formulae. During the experiment, data on plant height $(\mathrm{cm})$, siliqua length, siliqua number per plant, panicles plant ${ }^{-1}$, seed, and stover yield $\left(\mathrm{q} \mathrm{ha}{ }^{-1}\right)$ were recorded at various growth phases. To compare the treatment means, data was examined statistically using Fisher's analysis of variance approach and critical difference (CD) at a 5\% probability level.

Table 1 Physico-chemical properties of the initial soil sample

\begin{tabular}{|c|c|c|}
\hline \multicolumn{2}{|c|}{ Characteristics } & Value \\
\hline \multirow{3}{*}{ Texture } & Sand $(\%)$ & 52.33 \\
\hline & Silt(\%) & 30.64 \\
\hline & Clay $(\%)$ & 17.10 \\
\hline & class & Sandy loam \\
\hline $\mathrm{pH}$ & ter suspension & 8.3 \\
\hline EC $(1: 2$. & uspension $\left(\mathrm{dSm}^{-1}\right)$ & 0.23 \\
\hline & bon $(\%)$ & 0.49 \\
\hline & gen $\left(\mathrm{kgha}^{-1}\right)$ & 185 \\
\hline & orus $\left(\mathrm{kgha}^{-1}\right)$ & 12 \\
\hline & ium $\left(\mathrm{kg} \mathrm{ha}^{-1}\right)$ & 161 \\
\hline & 1 soil day $^{-1}$ ) & 118 \\
\hline & ${ }^{1}$ Soil $\mathrm{h}^{-1}$ ) & 129 \\
\hline & $\mathrm{g}^{-1}$ soil h$^{-1}$ ) & 41 \\
\hline
\end{tabular}

\subsection{Experimental soil}

In a 1:2.5 soil-water suspension, initial soil samples from each plot were obtained and analyzed for $\mathrm{pH}$ using the potentiometer technique (Jackson 1973). The electrical conductivity, which was expressed in $\mathrm{dSm}^{-1}$, was calculated using Conductivity Bridge. Standard methods were used for soil nutrient analysis, including organic carbon, alkaline $\mathrm{KMnO}_{4}-\mathrm{N}$, Olsen-P, $\mathrm{NH}_{4} \mathrm{OAc}-\mathrm{K}$ (Walkley \& Black 1934; Olsen, 1954; Subbiah \& Asija 1956; Truog, 1960; Jackson 1973), dehydrogenase, and urease activities by colorimeter method (Tabatabai, 1982; Tabatabai \& Bremner, 1986; Tabatabai, 1994), dehydrogenase and urease activities During the Rabi season in October 2019, seeds were sown in alluvial soils and reacted virtually neutrally with low soluble salts $\left(0.23 \mathrm{dSm}^{-1}\right)$, low organic carbon (0.49 percent) and available nitrogen (185 kg ha $\left.{ }^{-1}\right)$, medium phosphorus $\left(12 \mathrm{~kg} \mathrm{ha}^{-1}\right)$ and medium available potassium $\left(161 \mathrm{~kg} \mathrm{ha}^{-1}\right)$ in table 1 . Because most farmers in the region plant it frequently, the mustard variety Ashirwad was used at a seed rate of $6 \mathrm{~kg} \mathrm{ha}^{-1}$ soil was plowed and seeded before planting. Urea, diammonium phosphate (DAP), and potash muriate were utilized as the nitrogen $(\mathrm{N})$, phosphorus $(\mathrm{P})$, and potassium $(\mathrm{K})$ sources (MOP). During field preparation, the whole amount of $\mathrm{P}, \mathrm{K}$, and half of the $\mathrm{N}$ was applied, with the remaining $\mathrm{N}$ applied 30 days later. The crop was collected physically during the third week of February 2019. After the mustard harvest, soil samples were taken from the top layer (0-15 $\mathrm{cm})$ and analyzed.

\section{Results and Discussion}

\subsection{Growth and yield}

Among the tested treatments, $\mathrm{T}_{7}$ had the most growth and yield, whereas $T_{1}$ had the lowest. Mustard plants were between 106.30 and $131.20 \mathrm{~cm}$ tall. $\mathrm{T}_{7}$ was the plant with the highest fresh weight, ranging from 11.16 to $18.90 \mathrm{~g}$. The balanced nutrients supply was responsible for better yield, net benefits, and $\mathrm{B}$ : $\mathrm{C}$ ratio compared to control and blanket treatments, and this might be owing to the synergistic impact of the concurrent addition of multiple sources of

Table 2 Growth and yield parameters of mustards influenced by different approaches of nutrient management

\begin{tabular}{|c|c|c|c|c|c|c|c|}
\hline Treatments & $\begin{array}{l}\text { Plant height at } \\
\text { harvest }(\mathrm{cm})\end{array}$ & $\begin{array}{l}\text { Length of } \\
\text { Siliqua }\end{array}$ & $\begin{array}{l}\text { No. of Silqua } \\
\text { Plant }^{-1}\end{array}$ & $\begin{array}{l}\text { Seed yield } \\
\left(\mathrm{q} \mathrm{ha}^{-1}\right)\end{array}$ & $\begin{array}{l}\text { Stover yield } \\
\qquad\left(\mathrm{q} \mathrm{ha}^{-1}\right)\end{array}$ & $\begin{array}{c}\text { Deviation in seed yield } \\
\text { From target }(\%)\end{array}$ & $\begin{array}{l}\text { Increase in seed yield } \\
\text { Over RDF (\%) }\end{array}$ \\
\hline $\mathrm{T}_{1}$ & 106.30 & 4.30 & 192.00 & 8.8 & 36.1 & - & - \\
\hline $\mathrm{T}_{2}$ & 110.23 & 4.52 & 197.33 & 11.1 & 44.1 & - & - \\
\hline $\mathrm{T}_{3}$ & 115.52 & 4.54 & 204.71 & 16.5 & 46.7 & - & - \\
\hline $\mathrm{T}_{4}$ & 119.31 & 4.83 & 211.32 & 16.6 & 52.3 & -7.78 & 0.61 \\
\hline $\mathrm{T}_{5}$ & 127.65 & 5.34 & 232.00 & 21.5 & 62.8 & -4.65 & 27.13 \\
\hline $\mathrm{T}_{6}$ & 124.40 & 4.94 & 219.34 & 18.6 & 57.2 & 3.33 & 12.05 \\
\hline $\mathrm{T}_{7}$ & 131.20 & 5.85 & 240.00 & 22.7 & 65.6 & 3.89 & 37.58 \\
\hline $\mathrm{CD}(\mathrm{P}=0.05)$ & 2.551 & 0.156 & 2.96 & 0.004 & 1.741 & - & - \\
\hline \multicolumn{8}{|c|}{ 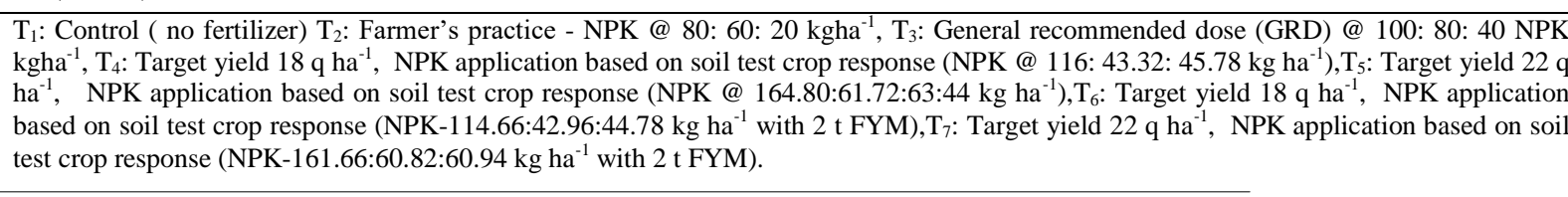 } \\
\hline
\end{tabular}

Journal of Experimental Biology and Agricultural Sciences

http://www.jebas.org 
nutrients (Sharma \& Singhal 2014; Sellamuthu et al., 2015). Before farmer practices, $\mathrm{T}_{7}\left(22.7 \mathrm{q} \mathrm{ha}^{-1}\right)$ was followed by $\mathrm{T}_{5}\left(18.60 \mathrm{q} \mathrm{ha}^{-1}\right)$ and GRD (16.5 q ha $\mathrm{q}^{-1}$ (11.10 q ha $\left.{ }^{-1}\right)$. The expected yield was substantially higher than GRD and farmer practices, according to these data (Table 2). Further, $\mathrm{T}_{7}$ outperformed the others by 37.58 percent when compared to RDF. The objective yield was within 5\% of the projected value, illustrating the precision of the equations for prescribing integrated fertilizer doses in mustard. The biggest net benefit came from a targeted yield of $22 \mathrm{q} \mathrm{ha}^{-1}(55,190.00)$, followed by a targeted yield of 18 qha $^{-1}(38,583.00)$, GRD $(28,221)$, and farmers' practices (5479.00). Targeted yield $22 \mathrm{q} \mathrm{ha}^{-1}$ (6.23) had the highest B: C ratio, followed by targeted yield $18 \mathrm{q} \mathrm{ha}^{-1}$ (6.21), (5.84).

\subsection{Economic performance}

The cost of cultivation, extra cost, and net profit were all significantly greater with the STCR treatments, according to the economics of mustard crop farming under various treatments. The $\mathrm{T}_{7}$ treatment had the highest actual yield, whereas the NPK+FYM application had the highest extra cost in table 3 . With an additional cost of Rs 55,190, $T_{7}$ had the highest net benefit, while $T_{1}$ had the lowest. Treatment $\mathrm{T} 1$ had the lowest benefit-to-cost ratio (1.03), while treatment $T_{7}$ had the greatest $(6.23)$. Treatment $T_{7}(16,607)$ showed the most advantage over the prescribed fertilizer dose, whereas treatment $\mathrm{T}_{4}$ showed the least (8688.42). In other words, when compared to farmers' practices and general recommendations, the treatment of targeted yield $22 \mathrm{q} \mathrm{ha}^{-1}$ was determined to be the most cost-effective (Singh et al., 2015).

\subsection{Nutrient uptake}

Like other parameters, treatment $\mathrm{T}_{7}\left(284.55 \mathrm{~kg} \mathrm{ha}^{-1}\right)$ had the highest total nutrient absorption (seed + stover) for a targeted yield of $22 \mathrm{q} \mathrm{ha}^{-1}$, whereas $\mathrm{T}_{6}\left(228.17 \mathrm{~kg} \mathrm{ha}^{-1}\right)$ had the lowest for a target yield of $18 \mathrm{q} \mathrm{ha}^{-1}$. The total nutrient absorption in the case of the prescribed fertilizer dose is $170.08 \mathrm{~kg} \mathrm{ha}^{-1}$, which is greater than $\mathrm{T}_{2}$ $\left(139.59 \mathrm{~kg} \mathrm{ha}^{-1}\right)$ in table 4 . The use of FYM, which made it easier for roots to absorb nutrients and improved soil conditions, increased nutrient absorption. The expansion of roots and increased synchronicity between supply and demand were facilitated by high soil health based on table 5, which absorbed more nutrients from the north of the country and depth (Tiwari, 2001; Singh et al., 2015).

In 2019, the amount of accessible nitrogen rose considerably in all treatments except the control plot. However, there was a notable increase in STCR treatments, which went from very low to medium from 187 to $216 \mathrm{~kg} \mathrm{ha}^{-1}$ in the low category. In the case of $\mathrm{K}_{2} \mathrm{O}$ and $\mathrm{P}_{2} \mathrm{O}_{5}$, the $\mathrm{P}$ and $\mathrm{K}$ status significantly improved in all treatments except $T_{1}$ (control plot). Because of the usage of NPK+FYM, higher levels of these parameters were seen in STCR treatments, particularly in $\mathrm{T}_{7}$.

Table 3 Effect of different treatments on net benefit and economics of mustard crop

\begin{tabular}{|c|c|c|c|c|c|c|c|c|}
\hline Treatments & $\begin{array}{c}\text { Actual mean } \\
\text { yield }\left(\mathrm{kg} \mathrm{ha}^{-1}\right)\end{array}$ & $\begin{array}{l}\text { Additional yield } \\
\left(\mathrm{kg} \mathrm{ha}^{-1}\right)\end{array}$ & $\begin{array}{c}\text { Cost of fertilizer } \\
\left(\mathrm{Rs} \mathrm{ha}^{-1}\right)\end{array}$ & $\begin{array}{l}\text { Additional Cost } \\
\text { (Rs) }\end{array}$ & $\begin{array}{l}\text { Net benefit } \\
\text { (Rs) }\end{array}$ & $\begin{array}{l}\text { Benefit cost } \\
(\mathrm{B}: \mathrm{C}) \text { ratio }\end{array}$ & $\begin{array}{l}\text { Deviation in } \\
\text { yield }(\%)\end{array}$ & $\begin{array}{c}\text { Benefits over R } \\
\text { D F }\end{array}$ \\
\hline $\mathrm{T}_{1}$ & 878 & - & - & - & - & - & - & - \\
\hline $\mathrm{T}_{2}$ & 1112 & 234 & 5299 & 10779 & 5479 & 1.03 & - & - \\
\hline $\mathrm{T}_{3}$ & 1650 & 772 & 7305 & 35527 & 28221 & 3.86 & - & - \\
\hline $\mathrm{T}_{4}$ & 1660 & 548 & 5674 & 25208 & 19533 & 3.44 & -7.78 & -8688.42 \\
\hline $\mathrm{T}_{5}$ & 2098 & 1220 & 8028 & 56120 & 48091 & 5.99 & -4.65 & 28557.55 \\
\hline $\mathrm{T}_{6}$ & 1860 & 982 & 6604 & 45187 & 38583 & 5.84 & 3.33 & -9508.01 \\
\hline $\mathrm{T}_{7}$ & 2270 & 1392 & 8857 & 64047 & 55190 & 6.23 & 3.89 & 16607.22 \\
\hline
\end{tabular}

Mustard@Rs.44.5/kg, Urea@Rs.56.25/kg, DAP@Rs56.25/kg, MOP@Rs26.66/kg, FYM@Rs0.5/kg

Table 4 Effect of different treatments on nutrient uptake by Mustard

\begin{tabular}{|ccccccccccc|}
\hline & \multicolumn{3}{c}{ Seed Uptake $\left(\mathrm{kgh}^{-1}\right)$} & \multicolumn{3}{c}{ Stover Uptake $\left(\mathrm{kg} \mathrm{ha}^{-1}\right.$} & \multicolumn{5}{c|}{ Total Uptake $\left(\mathrm{kg} \mathrm{ha}^{-1}\right)$} \\
\hline Treatments & $\mathrm{N}$ & $\mathrm{P}$ & $\mathrm{K}$ & $\mathrm{N}$ & $\mathrm{P}$ & $\mathrm{K}$ & $\mathrm{N}$ & $\mathrm{P}$ & $\mathrm{K}$ \\
\hline $\mathrm{T}_{1}$ & 19.63 & 3.72 & 7.76 & 4.15 & 1.73 & 12.29 & 41.31 & 6.23 & 51.53 \\
\hline $\mathrm{T}_{2}$ & 25.87 & 4.86 & 9.82 & 5.86 & 2.63 & 16.38 & 59.20 & 9.92 & 70.47 \\
\hline $\mathrm{T}_{3}$ & 39.27 & 7.43 & 14.74 & 8.64 & 4.18 & 24.48 & 72.58 & 12.43 & 85.07 \\
\hline $\mathrm{T}_{4}$ & 39.44 & 7.64 & 14.87 & 8.82 & 4.48 & 24.73 & 80.98 & 14.39 & 99.95 \\
\hline $\mathrm{T}_{5}$ & 50.20 & 10.8 & 19.23 & 11.81 & 5.94 & 31.58 & 99.96 & 19.19 & 132.92 \\
\hline $\mathrm{T}_{6}$ & 44.45 & 8.68 & 16.80 & 9.73 & 5.06 & 27.90 & 95.77 & 17.42 & 114.98 \\
\hline $\mathrm{T}_{7}$ & 53.42 & 11.58 & 21.11 & 13.17 & 6.51 & 34.2. & 116.16 & 23.07 & 145.32 \\
\hline $\mathrm{CD}(\mathrm{P}=0.05)$ & 0.010 & 0.006 & 0.015 & 0.039 & 0.039 & 0.023 & - & - & - \\
\hline
\end{tabular}


Table 5 Physicochemical properties and fertility status of the post-harvest soil

\begin{tabular}{|cccccccc|}
\hline Treatments & $\mathrm{pH}$ & Physico-chemical properties EC $\left(\mathrm{dS} \mathrm{m}^{-1}\right)$ & $\mathrm{OC}(\%)$ & $\mathrm{N}$ & Fertility status $\mathrm{P}_{2} \mathrm{O}_{5}\left(\mathrm{Kg} \mathrm{ha}^{-1}\right)$ & $\mathrm{K}_{2} \mathrm{O}$ \\
\hline $\mathrm{T}_{1}$ & 8.17 & 0.152 & 0.32 & 187 & 15.003 & 166.2 \\
\hline $\mathrm{T}_{2}$ & 8.21 & 0.154 & 0.34 & 189 & 17.120 & 169.1 \\
\hline $\mathrm{T}_{3}$ & 8.23 & 0.159 & 0.38 & 196 & 18.163 & 175.1 \\
\hline $\mathrm{T}_{4}$ & 8.20 & 0.163 & 0.41 & 203 & 21.840 & 178.9 \\
\hline $\mathrm{T}_{5}$ & 8.13 & 0.168 & 0.49 & 212 & 24.300 & 185.4 \\
\hline $\mathrm{T}_{6}$ & 8.03 & 0.164 & 0.47 & 211 & 22.427 & 182.0 \\
\hline $\mathrm{T}_{7}$ & 7.97 & 0.173 & 0.47 & 216 & 26.103 & 186.8 \\
\hline $\mathrm{CD}(\mathrm{P}=0.05)$ & 0.134 & 0.003 & 0.017 & 2.16 & 0.87 & - \\
\hline
\end{tabular}

Table 6 Soil enzyme activities in post-harvest soil

\begin{tabular}{|c|c|c|c|c|c|c|}
\hline \multirow{2}{*}{ Treatments } & \multicolumn{2}{|c|}{$\begin{array}{l}\text { Urease Activity } \\
\left(\mu \mathrm{g} \mathrm{g}^{-1} \text { soil h}^{-1}\right)\end{array}$} & \multicolumn{2}{|c|}{$\begin{array}{l}\text { Dehydrogenase activity } \\
\left(\mu \mathrm{g} \text { TPF } \mathrm{g}^{-1} \text { soil }^{-1}\right)\end{array}$} & \multicolumn{2}{|c|}{$\begin{array}{l}\text { Alkaline Phosphatase activity } \\
\left(\mu \mathrm{g} \text { - nitrophenol } \mathrm{g}^{-1} \text { soil }^{-1}\right)\end{array}$} \\
\hline & $\mathrm{BT}$ & $\mathrm{AH}$ & BT & $\mathrm{AH}$ & BT & $\mathrm{AH}$ \\
\hline $\mathrm{T} 1$ & 182 & 183.04 & 121 & 125.00 & 45.0 & 47.35 \\
\hline 77 & 182 & 191.60 & 121 & 140.30 & 45.0 & 68.40 \\
\hline $\mathrm{T} 3$ & 182 & 199.19 & 121 & 144.50 & 45.0 & 78.90 \\
\hline $\mathrm{T} 4$ & 182 & 208.30 & 121 & 151.35 & 45.0 & 86.37 \\
\hline T5 & 182 & 220.25 & 121 & 162.34 & 45.0 & 100.55 \\
\hline T6 & 182 & 214.33 & 121 & 166.60 & 45.0 & 90.15 \\
\hline $\mathrm{T} 7$ & 182 & 226.39 & 121 & 177.23 & 45.0 & 116.50 \\
\hline $\mathrm{CD}$ at $5 \%$ & NS & 7.10 & NS & 10.79 & NS & 0.87 \\
\hline
\end{tabular}

\subsection{Urease activity}

Enzyme activity is thought to be a key contributor to total soil microbial activity in the soil environment (Table 6). The colorimeter technique is used to measure urease enzyme activity. In the farmer field experiment, the soil concentrations varied from 183.04 to $226.39 \mathrm{~g}$ per gram of soil $\mathrm{h}^{-1}$. $(184.07 \mathrm{~g})$ is the bare minimum. The lowest urease enzyme activity was reported in the control plot, while it was reported highest $(226.39 \mathrm{~g})$ in the treatment $\mathrm{T}_{7}$ plot.

\subsection{Dehydrogenase activity}

The colorimeter technique is used to evaluate the activity of the dehydrogenase enzyme. In the farmer field experiment, the TPF $\mathrm{g}^{-1}$ soil $\mathrm{h}^{-1}$ varied between 125.0 and $177.23 \mathrm{~g}(124.0 \mathrm{~g})$ is the bare minimum. Dehydrogenase enzyme activity was measured in control plot $\mathrm{T}_{1}$, however, it was highest in treatment plot $\mathrm{T}_{7}$ (177.23 $\mathrm{g} \mathrm{TPF} \mathrm{g}^{-1}$ soil h$^{-1}$ ).

\subsection{Alkaline phosphatase}

The colorimetric analysis is used to assess alkaline phosphate enzyme activity. In the farmer field experiment, the p-nitrophenol $\mathrm{g}^{-1}$ soil $\mathrm{h}^{-1}$ varied from 47.50 to $116.50 \mathrm{~g}$ p-nitrophenol $\mathrm{g}^{-1} \mathrm{soil} \mathrm{h}^{-1}$. The alkaline phosphatase activity in control was $45.63 \mathrm{~g} \mathrm{p}$ nitrophenol $\mathrm{g}^{-1}$ soil $^{-1}$, whereas it was $116.50 \mathrm{~g}$ p-nitrophenol $\mathrm{g}^{-1}$ soil $\mathrm{h}^{-1}$ in treatment $\mathrm{T}_{7}$.

As compared to other nutrient management systems, the STCR technology appears to be an acceptable strategy for optimum nutrient supply that improves soil characteristics, particularly soil health and production, over time. The findings showed that an STCR strategy to integrated nutrient delivery with inorganic fertilizers is required for productivity and sustainability, as well as improved gross returns and benefit-cost ratios. The use of FYM and inorganic fertilizers in combination improved chemical and physical characteristics as well as enzyme activity, potentially leading to increased and sustainable output (Tadesse et al., 2013).

\section{Conclusion}

As compared to other nutrient management systems, the STCR technology appears to be an acceptable strategy for optimum nutrient supply that improves soil characteristics, particularly soil health and production, over time. The findings showed that an STCR strategy to integrated nutrient delivery with inorganic 
fertilizers is required for productivity and sustainability, as well as improved gross returns and benefit-cost ratios. The use of FYM and inorganic fertilizers in combination improved chemical and physical characteristics as well as enzyme activity, potentially leading to increased and sustainable output.

The accuracy of the equations for prescribing integrated fertilizer dosages for mustard in verification trials was within 5\%, demonstrating the validity of the calculations. The verification study revealed that STCR-INM 18 and $22 \mathrm{q} \mathrm{ha}^{-1}$ had considerably greater seed production. GRD and farmer practices, on the other hand, resulted in a lower yield. The response rate and accomplishment of the STCR-INM were both greater.

Due to soil test-based fertilizer recommendations under INM, the available $\mathrm{N}, \mathrm{P}$, and $\mathrm{K}$ status in soil indicated the build-up and maintenance of soil fertility. Fertilizer recommendations for farmers' practices were $80 \mathrm{~N}: 60 \mathrm{P}: 20 \mathrm{~K} \mathrm{~kg} \mathrm{ha}^{-1}$ and $114.66 \mathrm{~N}$ : 42.96 P: $44.7 \mathrm{~K} \mathrm{~kg} \mathrm{ha}^{-1}+2$ tones FYM for $22 \mathrm{q} \mathrm{ha}^{-1}$ goal yield treatment based on soil test value. So, in the Eastern plain Zone of India (Inceptisol) in Uttar Pradesh, the fertilizer prescription equations established for mustard under INM may be suggested for achieving yield targets of 18 and $22 \mathrm{q} \mathrm{ha}^{-1}$ while maintaining soil health.

\section{Acknowledgements}

The authors are thankful to the Head of the Department of Soil Science and Agricultural Chemistry, Institute of Agricultural Sciences, Banaras Hindu University, Varanasi, India for providing necessary facilities during the investigation.

\section{References}

Badiane NNY, Chotte L, Pate E, Masse D, Rouland C (2001) Use of soil enzyme activities to monitor soil quality in natural and improved fallows in semi-arid tropical regions. Applied Soil Ecology 18: 229-238.

Hegde DM (2012) Carrying capacity of Indian agriculture oilseeds Current Science 102(6): 867 -873.

Jackson ML (1973) Soil Chemical Analysis. Prentice Hall of India Pvt. Ltd., New Delhi.

Mandal A, Patra AK, Singh D, Swarup A, Masto RE (2007) Effect of long-term application of manure and fertilizer on biological and biochemical activities in soil during crop development stages. Bioresource Technology 98(18): 3585-3592.

Olsen SR (1954) Estimation of Available Phosphorus in Soils by Extraction with Sodium Bicarbonate.United States Department of Agriculture, Washington.
Ramakrishna Parama VR, Munawery A (2012) Sustainable soil nutrient management. Journal of the Indian Institute of Science 92: 1-8.

Rao S, Srivastava S (2000) Soil test based fertilizer use-a must for sustainable agriculture. Fertilizer News 45: 25-38.

Regar KL, Singh YV (2014) Fertilizer recommendation based on soil testing for the targeted yield of rice in easternplain zone of Utter Pradesh. The Bioscan 9(2): 531-534.

Sellamuthu KM, Santh IR, Maragatham S, Dey P (2015) Validation of soil test and yield target based fertilizer prescription model for wheat on Inceptisols. Research on Crops 16(1): 53-58.

Sharma V, Singhal S (2014) Validation of soil test based fertilizer prescriptions for targeted yield of pearlrice, wheat and mustard at farmer, s field. Annals of Plant and Soil Research 16(4): 367-371.

Singh AK, Gautam SUS, Singh J, Singh A, Shrivastava P (2015) Impact of nutrient management technologies intransplanted rice under irrigated domains of Central India. African Journal of Agricultural Science 10(5): 345-350.

Subbiah BV, Asija GL (1956) A rapid procedure for assessment of available nitrogen to rice plots. Current Science 31: 196-200.

Tabatabai MA (1982) Soil Enzymes in method of soil analysis part- II Ed. Page, A.-1, Miller RH and Kannedy DR), American Society of Agronomy, Wisconsin, USA.

Tabatabai MA (1994) Soil enzymes In: Weaver RW, Angle JS and Bottomley PS (Eds.) Methods of soil analysis, part 2.Microbiological and biochemical properties. SSSA Book Series No. 5. Soil Science Society of America, Madison, Wisconsin, USA, Pp. 775-833.

Tabatabai MA, Bremner JM (1986) Use of pnitrophenylphosphate for assay of soil phosphatase activity. Soil Biology \& Biochemistry 1: 301-307.

Tadesse T, Dechassa N, Bayu W, Gebeyehu S (2013) Effects of farmyard manure and inorganic fertilizer application on soil physico-chemical properties and nutrient balance in rain-fed lowland rice ecosystem. American Journal of Plant Sciences 4(2): 309-316.

Tiwari KN (2001) Phosphorus needs of Indian soils and crops. Better Crops International 15(2): 6-10.

Truog E (1960) Fifty years of soil testing. Transactions of the $7^{\text {th }}$ International Congress of Soil Science Pp. 46-53.

Walkley A, Black CA (1934) An examination of degtazreff method for determining soil organic matter and a proved modification of chronic acid titration method. Soil Science 37: 29-38. 